Atos de Pesquisa em Educação - ISSN 1809-0354

Blumenau, v. 12, n.3, p.705-730, set./dez. 2017

DOI: http://dx.doi.org/10.7867/1809-0354.2017v12n3p705-730

\title{
ÍNDICE DE DESENVOLVIMENTO DA EDUCAÇÃO BÁSICA E O CONTEXTO ESCOLAR: UM ESTUDO DE CASO NO MUNICÍPIO DE CAMPOS DOS GOYTACAZES - RJ
}

\section{BASIC EDUCATION DEVELOPMENT INDEX (IDEB) AND THE SCHOOL ROUTINE: A CASE STUDY IN CAMPOS DOS GOYTACAZES - RJ}

\author{
SOUZA, Luana Hespanhol de \\ hespanhol.luana@gmail.com \\ UENF - Universidade Estadual do Norte Fluminense Darcy Ribeiro \\ NEY, Marlon Gomes \\ marlonney@uenf.br \\ UENF - Universidade Estadual do Norte Fluminense Darcy Ribeiro \\ SOUZA, Paulo Marcelo de \\ pmsouza@uenf.br \\ UENF - Universidade Estadual do Norte Fluminense Darcy Ribeiro
}

\begin{abstract}
RESUMO O Índice de Desenvolvimento da Educação Básica (IDEB) se apresenta como uma das principais ferramentas de tomadas de decisões do governo em relação à educação. Contudo, o IDEB tem sido criticado por sua metodologia puramente quantitativa. O presente trabalho buscou analisar as percepções de professores em relação ao cotidiano escolar e ao indicador através de um estudo de caso em nove escolas estaduais localizadas em Campos dos Goytacazes - RJ. Foi adotada uma abordagem qualitativa e quantitativa, utilizando o método de aplicação de questionários e entrevistas semiestruturadas. A partir dos resultados é possível notar que o IDEB não é suficiente para descrever a qualidade de uma escola e não há grandes diferenças entre as escolas analisadas.
\end{abstract}

Palavras-chave: Avaliação externa. Educação básica. IDEB.

\begin{abstract}
The Basic Education Development Index (IDEB) appears as the indicator most used by the government to make decisions. However, the IDEB has been criticized for its purely quantitative methodology. Given the importance of education in the formation of citizens aware of their rights and duties, this study analyzed teachers' perceptions of the school routine and the index. The case study occurred in nine public schools located in Campos dos Goytacazes - RJ. It was adopted a quantitative and qualitative approach using the method of applying questionnaires and using interviews. From the results you can see that the IDEB isn't enough to describe the quality of a school, in addition, from the questionnaires was revealed that there is no big difference between the analyzed schools.
\end{abstract}

Keywords: Basic education. External evaluation. IDEB.

\section{INTRODUÇÃO}


Atos de Pesquisa em Educação - ISSN 1809-0354

Blumenau, v. 12, n.3, p.705-730, set./dez. 2017

DOI: http://dx.doi.org/10.7867/1809-0354.2017v12n3p705-730

A ampliação das vagas nas escolas públicas para crianças de sete a 14 anos possibilitou uma cobertura quase universal nesse nível (SILVA; MORAIS; BOF, 2006), contudo ao mesmo tempo ocorreu uma queda na qualidade de ensino. Pensando em soluções para monitorar e melhorar a qualidade das instituições públicas, na década de 1990, foi implantado o Sistema de Avaliação da Educação Básica (SAEB) pelo governo federal.

Nos dias atuais, o Índice de Desenvolvimento da Educação Básica (IDEB), criado em 2007 pelo Inep, apresenta-se como uma das principais ferramentas de tomadas de decisões do governo em relação à educação. A partir dos resultados, o indicador permite um monitoramento da "qualidade" das escolas, munícipios, estados e Brasil. Com isso, é possível identificar as escolas com piores e melhores desempenhos no IDEB. Um alto desempenho é entendido como uma melhora na qualidade do ensino ofertado pela escola; já um desempenho baixo mostra que a escola ainda não possui a qualidade ideal de ensino. $O$ ranqueamento dos resultados tem levado a políticas do tipo accountability, ou seja, responsabilização dos gestores educacionais e professores pela qualidade da educação ofertada.

O presente artigo tem como objetivo principal discutir o papel do IDEB como instrumento de política de avaliação da qualidade da educação básica e também identificar outras variáveis importantes para a avaliação das escolas. Para isso, foram analisadas as políticas de avaliação externas que ganharam força no Brasil a partir da década de 1990 e como surgiu o Índice de Desenvolvimento da Educação Básica (IDEB), bem como as principais críticas da literatura em relação ao índice. $O$ IDEB representa um grande avanço no que diz respeito às avaliações externas. Contudo, o indicador tem sido alvo de críticas por usar uma metodologia puramente quantitativa e levar em consideração apenas a Prova Brasil e o Fluxo Escolar. O artigo chama a atenção em relação à importância de contextualizar os resultados das escolas nas avaliações externas, buscando dessa forma compreender melhor uma realidade específica (RONCA, 2013; ALVES; SOARES, 2013).

\section{O ÍNDICE DE DESENVOLVIMENTO DA EDUCAÇÃO BÁSICA (IDEB)}


Atos de Pesquisa em Educação - ISSN 1809-0354

Blumenau, v. 12, n.3, p.705-730, set./dez. 2017

DOI: http://dx.doi.org/10.7867/1809-0354.2017v12n3p705-730

As políticas de avaliações externas têm sido utilizadas pelo país para diagnosticar o ensino das escolas, principalmente as públicas, buscando a partir dos resultados obtidos elaborar políticas voltadas para melhorar a qualidade do ensino. Em 2007, o INEP criou o Índice de Desenvolvimento da Educação Básica (IDEB), considerado hoje um dos principais indicadores da educação. Desde a sua primeira edição, o IDEB tem sido destaque por divulgar o ranking das escolas participantes bem como as projeções de metas para cada escola.

O IDEB combina informações sobre exames padronizados, Prova Brasil ou SAEB, realizados pelos estudantes no final das etapas de ensino $\left(5^{\circ}\right.$ ano, $9^{\circ}$ ano do ensino fundamental e $3^{\circ}$ ano do ensino médio), com informações do fluxo escolar. A combinação dessas duas variáveis é expressa em valores de 0 a 10 , mostrando a evolução dos sistemas de ensino nacional, por estados e munícipios. Os resultados do índice do Brasil, estados, municípios e das escolas são divulgados a cada dois anos e auxiliam na criação de políticas públicas.

Dessa forma, "esse novo contexto coloca ainda mais a escola pública em evidência, expondo os resultados de seu trabalho e ampliando a pressão pelo aumento das notas, entendido geralmente como melhoria da qualidade do ensino praticado" (MACHADO; ALAVARSE, 2014, p. 415). Ao mesmo tempo em que a divulgação dos resultados das escolas auxilia no desenvolvimento de políticas públicas, pode ocorrer também a análise dos dados sem levar em conta as especificidades e desafios de cada escola, o que acarreta muitas vezes responsabilização dos gestores educacionais pelo ensino ofertado.

Por isso, uma das maiores críticas relacionadas ao IDEB tem sido a falta de contextualização dos resultados com a realidade em que a escola está inserida. Contudo, no início de 2015, o INEP trouxe uma novidade ao seu portal. Agora é possível cruzar informações para mostrar o desempenho das escolas em seu contexto social.

Os dados gerados a partir das avaliações externas devem ser contextualizados sempre que analisados para evitar interpretações equivocadas (RONCA, 2013; ALVES; SOARES, 2013). Comparar uma escola localizada em bairro de classe média com uma de periferia, por exemplo, leva a uma análise desigual, pois os desafios enfrentados por cada uma são muito diferentes. Entender 
Atos de Pesquisa em Educação - ISSN 1809-0354

Blumenau, v. 12, n.3, p.705-730, set./dez. 2017

DOI: http://dx.doi.org/10.7867/1809-0354.2017v12n3p705-730

essas realidades distintas se faz necessário na elaboração de políticas que ajudem a diminuir a distância entre as escolas. Analisar apenas o indicador não permite compreender as desigualdades existentes, por isso é necessário ir além. As escolas com mais alunos com condições socioeconômicas desfavoráveis possuem maiores dificuldades de atingir a sua meta do IDEB (ALVES; SOARES, 2013).

Os critérios puramente quantitativos do IDEB também têm sido criticados; é necessário levar em consideração outras variáveis, além do fluxo escolar e Prova Brasil, "como infraestrutura e recursos pedagógicos, gestão educacional, formação de professores, condições de trabalho dos profissionais da educação, nível socioeconômico dos alunos, características étnico-raciais e outras" (RONCA, 2013, p. 80). Utilizar outras variáveis na análise da qualidade da educação no IDEB permite uma caracterização maior da escola e do contexto em que está inserida.

Entender uma realidade específica é importante para tomada de decisões. Não se pode pensar em políticas iguais para se implantar em realidades distintas, pois apesar de ter ocorrido a ampliação do acesso no nível fundamental de ensino, as fortes desigualdades regionais internas dos próprios sistemas não foram eliminadas (OLIVEIRA; ARAUJO, 2005).

O IDEB tem sua importância, porém ele não conta tudo; só a partir do acesso de um maior número de informações que é possível se aproximar de modo mais coerente de um diagnóstico, e assim tomar decisões mais plausíveis na busca pela ampliação da qualidade de educação da escola (CALDERANO; BARBACOVI; PEREIRA, 2013).

Outro aspecto de grande relevância está relacionado à responsabilização dos professores pelo fracasso ou sucesso do aluno. "Essa responsabilização parte do princípio de que é possível utilizar os resultados dos alunos para aferir o desempenho do professor" (MACHADO; ALAVARSE, 2014, p. 430). Contudo, muitos estudos apontam que os alunos estão sujeitos a outros fatores que estão fora do alcance dos professores (BOURDIEU, 1979; RONCA, 2013; MACHADO; ALAVARSE, 2014).

Na sala de aula, os professores não têm conhecimento sobre a vida pessoal de cada aluno, e ensina a todos da mesma forma. Assim, a própria escola cria desigualdades sociais ao tratar todos de forma igual (BOURDIEU,1966). Isso mostra 
Atos de Pesquisa em Educação - ISSN 1809-0354

Blumenau, v. 12, n.3, p.705-730, set./dez. 2017

DOI: http://dx.doi.org/10.7867/1809-0354.2017v12n3p705-730

a importância de políticas que possam atuar de forma conjunta, pensando não só em melhorar a educação, mas também as condições com que esses alunos são ensinados.

Os exames padronizados também podem trazer alguns riscos em relação à veracidade das notas obtidas. Com o intuito de aumentar a nota, algumas escolas podem excluir os alunos com baixo desempenho e se dedicarem apenas àqueles que possuem um desempenho melhor, já que a Prova Brasil é realizada apenas pelos alunos que estão presentes no dia de sua aplicação (FERNANDES; GREMAUD, 2009; RONCA, 2013). Esse problema também é conhecido como gaming, ou seja, estratégias que as escolas adotam para melhorar o índice, mas que não geram melhoras na qualidade da educação.

O sistema de metas que foi implantado junto ao IDEB também tem sofrido muitas críticas. A ideia principal é que dessa forma as escolas se comprometam mais em melhorar e obter bons resultados (FERNANDES; GREMAUD, 2009). As escolas que alcançam as metas estabelecidas são "premiadas" com o recebimento de maiores recursos para o investimento na educação e bonificação dos professores, enquanto as que não alcançam sua meta recebem uma verba menor. Dessa forma, a escola acaba sendo "penalizada", quando deveria receber mais atenção e assistência do governo. Esse tipo de política além de instigar a manipulação de dados, também tem gerado a concorrência entre as escolas (RONCA, 2013).

\section{INFORMAÇÕES SOBRE A BASE DE DADOS E A METODOLOGIA}

Buscando entender a realidade vivida pelas escolas estaduais com IDEB relativamente baixo, médio e alto, a pesquisa utilizou uma abordagem qualiquantitativa por meio da aplicação de questionários com perguntas fechadas e semiabertas, e de entrevista semiestruturada. O objetivo foi levantar dados referentes ao IDEB e ao cotidiano escolar das escolas pesquisadas, a partir da opinião dos professores de nove escolas estaduais. Para algumas perguntas do questionário, foi utilizada a escala likert de cinco pontos. Esse tipo de escala segue um padrão de pergunta que parte de "aprovo fortemente" até "desaprovo 
Atos de Pesquisa em Educação - ISSN 1809-0354

Blumenau, v. 12, n.3, p.705-730, set./dez. 2017

DOI: http://dx.doi.org/10.7867/1809-0354.2017v12n3p705-730

fortemente", além de possuir um ponto neutro no meio da escala (LIKERT, 1932). Apesar das críticas em relação a esse tipo de método, Dalmoro e Vieira (2014) mostram em um estudo de caso que a escala de cinco pontos se caracteriza por ser mais rápida e fácil comparada a outras.

As anotações de campo e observações da autora auxiliaram na interpretação dos dados. As escolas, localizadas em Campos dos Goytacazes - RJ, foram selecionadas de acordo com o seu desempenho no IDEB do ano de 2013. Algumas escolas inicialmente escolhidas optaram por não participar da pesquisa ou de alguma forma apresentavam dificuldades em colaborar, dessa forma três escolas tiveram de ser substituídas. Após a seleção, foram divididas em três grupos de números iguais: desempenho alto, médio e baixo. As escolas com desempenho médio foram selecionadas a partir da mediana.

O Quadro 1 apresenta as escolas escolhidas separadas por grupo e sua nota no IDEB. Os nomes das escolas apresentadas são fictícios. Foi decidido pela não divulgação para que os professores se sentissem mais seguros ao responderem as questões apresentadas. Mesmo com a não divulgação da escola e o nome do participante da pesquisa, alguns professores preferiram não colaborar.

Quadro 1 - Escolas escolhidas para o estudo de caso e seu desempenho no IDEB

\begin{tabular}{|l|l|l|}
\hline Desempenho & Escolas & Nota do IDEB \\
\hline \multirow{2}{*}{ Desempenho alto } & Escola A & 4,8 \\
& Escola B & 4,7 \\
& Escola C & 4,0 \\
\hline \multirow{2}{*}{ Desempenho médio } & Escola D & 3,5 \\
& Escola E & 3,4 \\
& Escola F & 3,4 \\
\hline \multirow{2}{*}{ Desempenho baixo } & Escola G & 2,9 \\
& Escola H & 2,9 \\
& Escola I & 2,8 \\
\hline
\end{tabular}

Fonte: Elaboração da autora, IDEB (2013).

Foram aplicados 222 questionários aos professores (em um universo de 424 professores) do ensino médio, nível escolhido por representar o último da educação básica; a amostra é satisfatória com $95 \%$ de nível de confiança e $5 \%$ de margem de 
Atos de Pesquisa em Educação - ISSN 1809-0354

Blumenau, v. 12, n.3, p.705-730, set./dez. 2017

DOI: http://dx.doi.org/10.7867/1809-0354.2017v12n3p705-730

erro. Foi utilizada a técnica de pesquisa survey, que tem como objetivo a coleta da opinião pública. Os pesquisadores abordavam todos os professores que estavam presentes nos dias de ida às escolas. Com os resultados, foi possível realizar uma comparação das respostas obtidas por professores das diferentes escolas analisadas. Os resultados possibilitaram comparar se o cotidiano escolar da escola com alto desempenho no IDEB é muito diferente da escola com baixo.

Após a aplicação dos questionários, foram realizadas 13 entrevistas semiestruturadas com os professores das escolas analisadas. As entrevistas foram padronizadas, pois o objetivo foi comparar as respostas para as mesmas perguntas. Além disso, as entrevistas possibilitaram uma complementação às perguntas fechadas do questionário. Foi utilizada a amostragem não probabilística por conveniência.

As estimativas passaram por ponderação, ou seja, cada observação (indivíduo entrevistado) foi multiplicada por um fator de expansão que representa o total de pessoas na população que ela representa: 2,37 (escola A), 1,91 (escola B), 1,88 (escola C), 2,67 (escola D), 2,25 (escola E), 1,56 (escola F), 1,73 (escola G), 1,21 (escola $\mathrm{H}$ ) e 2,04 (escola I). Além disso, foram desconsideradas todas as perguntas sem respostas ou que havia mais de uma opção selecionada.

Sobre o município escolhido, Campos dos Goytacazes se localiza no estado do Rio de Janeiro. Segundo informações do IBGE (2017), a população estimada para 2017 é igual a 490.288, com área territorial de 4.026.696 km². Em 2012, Campos estava entre os 11 municípios, excluindo as capitais, que se destacaram por gerarem individualmente mais de $0,5 \%$ do PIB, agregando $8,7 \%$ da renda do país. Apesar de ser destaque no PIB, não se pode dizer o mesmo do IDEB. Em 2013, o munícipio teve nota igual a 3,4. Houve aumento comparado com os outros anos, contudo ele continua sendo considerado com uma das piores notas do IDEB no estado do Rio de Janeiro. Os dados reforçam a necessidade de estudar o município.

\section{ANÁLISE DO COTIDIANO ESCOLAR E O IDEB: O QUE OS PROFESSORES TÊM A DIZER?}


Atos de Pesquisa em Educação - ISSN 1809-0354

Blumenau, v. 12, n.3, p.705-730, set./dez. 2017

DOI: http://dx.doi.org/10.7867/1809-0354.2017v12n3p705-730

No estudo de campo, o principal objetivo foi entender um pouco do contexto escolar através da opinião dos professores de escolas estaduais, buscando verificar se há uma grande diferença entre as escolas com notas altas e baixas no IDEB. Em relação à formação dos professores pesquisados, é possível notar pelos resultados que não há uma grande diferença entre os grupos de escolas. Destaca-se que a grande maioria dos entrevistados possui especialização, seguido de graduação (ver Gráfico 1).

Em relação ao doutorado, apenas uma minoria, no grupo baixo e médio desempenho, apresentou essa titulação. Um dos maiores desafios no Brasil está relacionado com a formação do professor da educação básica (CRUZ; MONTEIRO, 2013). Dessa forma, é necessário assegurar que todos os educadores tenham formação em nível superior, objetivo já preconizado na LDB/1996. Além disso, surge a necessidade de melhorar a qualidade da formação nos cursos de pedagogia e licenciaturas.

Gráfico 1 - Percentual de professores com graduação, especialização, mestrado e doutorado, conforme categoria de desempenho no IDEB.

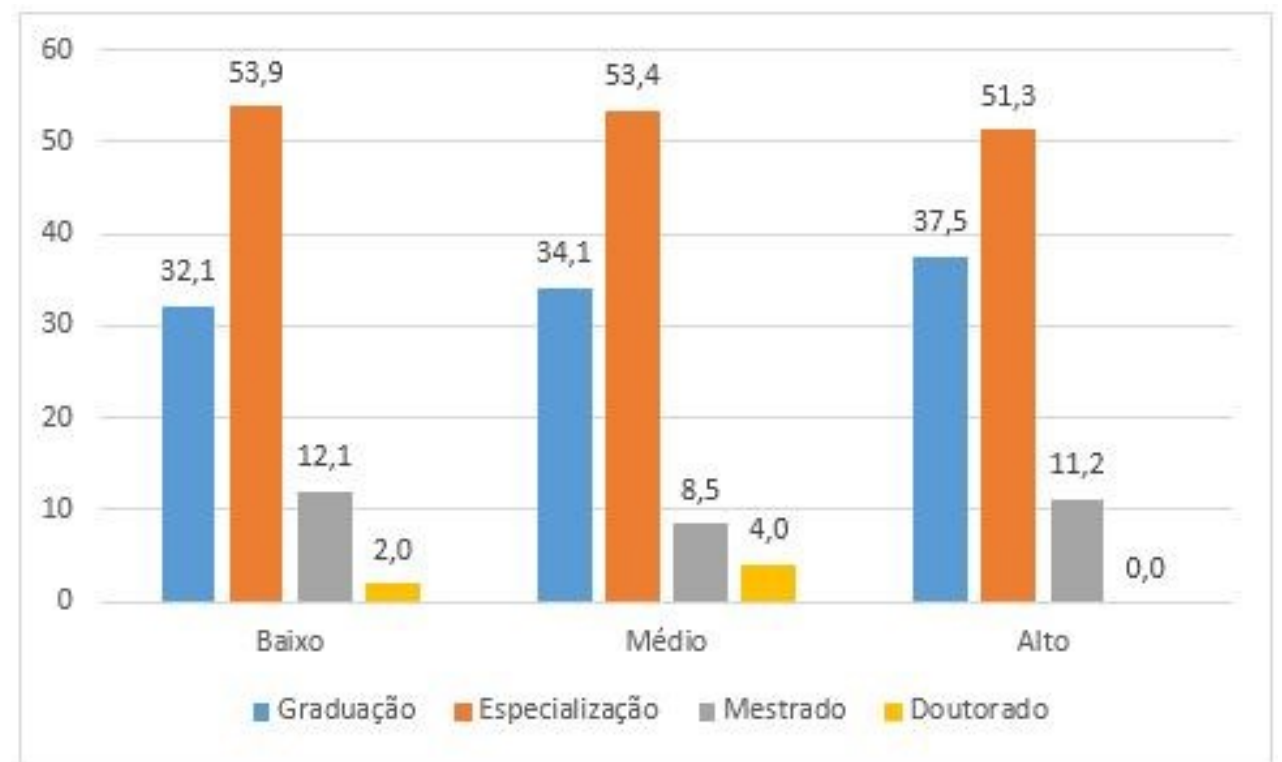

Fonte: Elaboração da autora

Outro aspecto que tem recebido muita atenção é a política de reforço escolar. Ela tem como objetivo ajudar os alunos com maiores dificuldades, bem como auxiliar em estratégias de "realfabetização" para combater o analfabetismo funcional, 
Atos de Pesquisa em Educação - ISSN 1809-0354

Blumenau, v. 12, n.3, p.705-730, set./dez. 2017

DOI: http://dx.doi.org/10.7867/1809-0354.2017v12n3p705-730

realidade ainda presente nas escolas públicas. Entre 2009 e 2013, quase 38 mil alunos foram "realfabetizados" no estado do Rio de Janeiro, fazendo o índice de analfabetismo ser reduzido para 3,1\% em 2013 (RIO DE JANEIRO, 2015). Mas será que a política de reforço é uma realidade para as escolas do interior? Os resultados mostram que a pior situação em relação ao reforço se encontra nas escolas do grupo médio, em que $74,6 \%$ dos professores entrevistados disseram que tal política não existe (Gráfico 2). Já as escolas do grupo alto e baixo possuem resultados próximos, contudo é o grupo alto que se destaca com $65 \%$ dos entrevistados dizendo que a política de reforço é realidade nas escolas em que trabalham. Porém, só a existencia do reforço escolar não é suficiente.

Gráfico 2 - Proporção de professores que conhecem o funcionamento de alguma política de reforço escolar na escola, conforme categoria de desempenho da escola no IDEB (em \%).

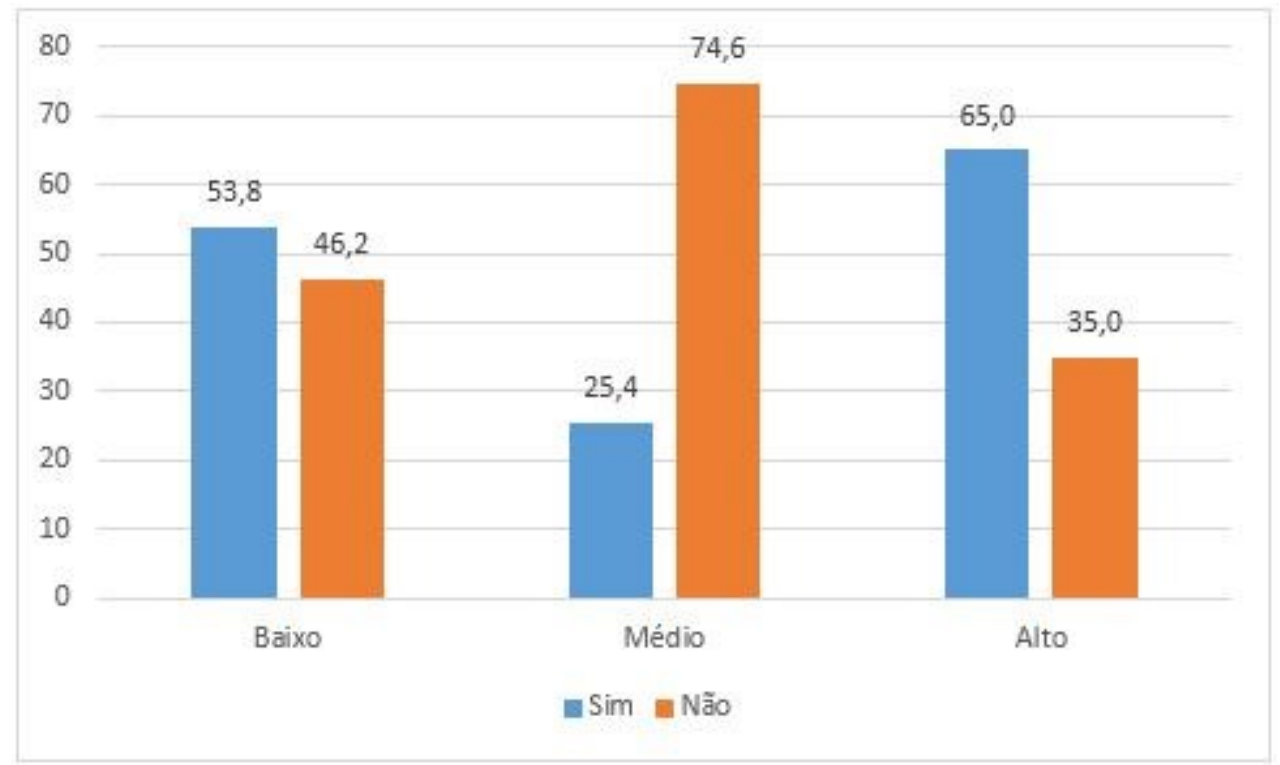

Fonte: Elaboração da autora

É necessário saber se essa política funciona bem, por isso os professores que responderam "sim" foram questionados sobre isso (Gráfico 3). Em todos as categorias de IDEB, a proporção de professores que responderam que a política de reforço escolar "não funciona bem" prevalece, principalmente no médio, com 86,6\%, e no baixo, com $70,1 \%$. O grupo alto mantém quase um equilíbrio nas respostas. Dessa forma, os resultados chamam atenção para a atual política de reforço existente ou não nessas escolas. Como se trata de uma política tão importante, 
Atos de Pesquisa em Educação - ISSN 1809-0354

Blumenau, v. 12, n.3, p.705-730, set./dez. 2017

DOI: http://dx.doi.org/10.7867/1809-0354.2017v12n3p705-730

sugerem-se maiores debates em relação a sua eficácia e sua importância. É provável que ela tenha contribuído substancialmente para que as escolas $A, B$ e $C$ tivessem notas mais elevadas no IDEB. Nota-se que no grupo alto ocorreu a maior proporção de professores reconhecendo a existência da política de reforço escolar, bem como seu bom funcionamento.

Gráfico 3 - Proporção de professores que disseram que a política de reforço escolar funciona bem na escola em que trabalham, entre os que afirmaram que existe tal política, conforme categoria de desempenho da escola no IDEB (em \%).

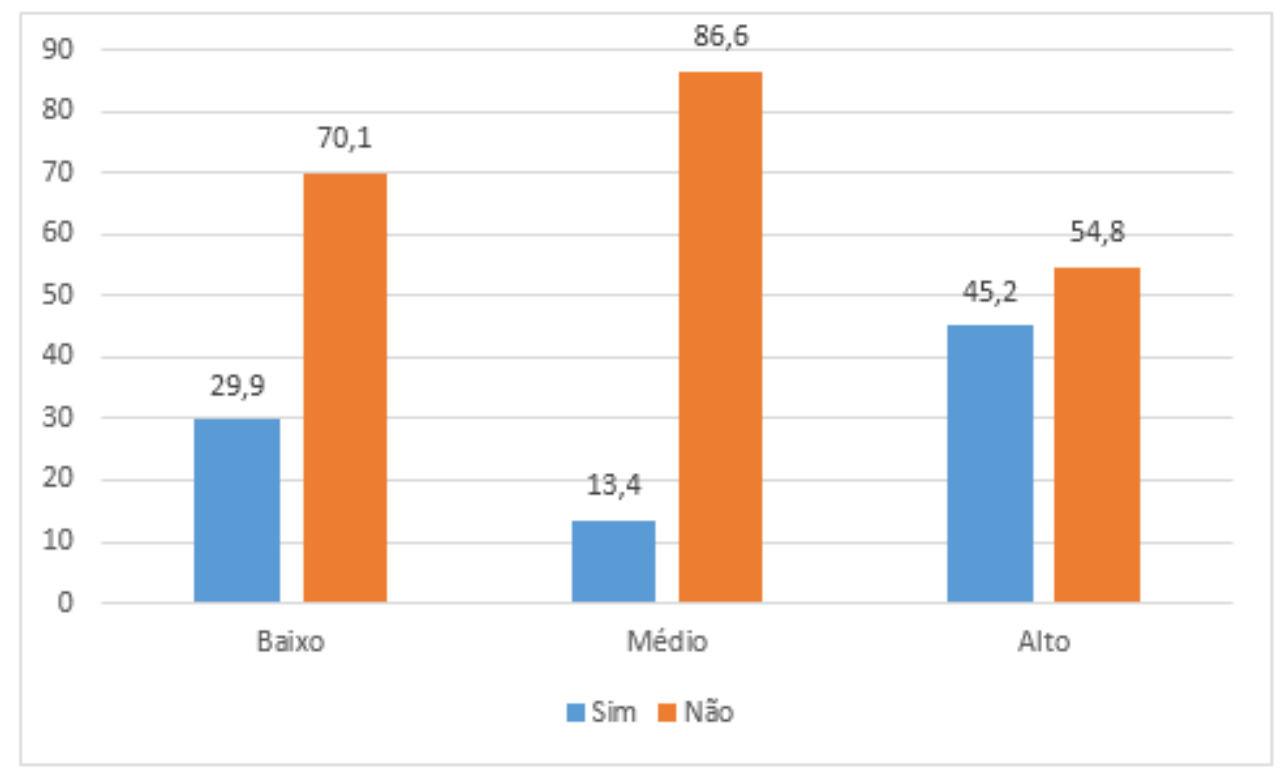

Fonte: Elaboração da autora

O aluno que tem mais dificuldade pode ser beneficiado por tal política, além de ter uma chance maior de melhorar seu desempenho sem que seja necessário o uso da "aprovação automática". Evidentemente a questão não é tão simples, o aluno também precisa se esforçar, pois não adiantará um boa política de reforço se ele não estiver interessado. É necessário, porém, que haja a iniciativa para que depois os desafios que forem surgindo sejam superados por meio de uma política bem estruturada voltada principalmente para o contexto socioeconômico dos alunos. Levantar a discussão entre as escolas e as comunidades sobre a importância do ensino se faz necessário em um contexto em que poucos se preocupam com a trajetória escolar do filho, como mostrarão os resultados. 
Atos de Pesquisa em Educação - ISSN 1809-0354

Blumenau, v. 12, n.3, p.705-730, set./dez. 2017

DOI: http://dx.doi.org/10.7867/1809-0354.2017v12n3p705-730

Os professores também foram questionados sobre a utilização de outros materiais, além do livro didático, para completar o conteúdo das aulas. A utilização de recursos complementares pode contribuir para o melhor entendimento do aluno, contudo não se pode negar a importância que o livro possui. Porém, de acordo com os resultados do Gráfico 4, não parece ser o uso de outros materiais didáticos que tenha contribuído para que as escolas $A, B$ e $C$ se destaquem com melhor IDEB. Em todos os grupos, é baixíssima a proporção de docentes que afirmam que raramente ou nunca usam outros materiais didáticos. Nesse sentido, os resultados se aproximam. Contudo, surge as questões: a escola tem dado suporte para que os professores utilizem outros materiais em sala de aula? Existem equipamentos necessários para que os professores possam usar outros tipos de materiais como vídeos, slides, música, etc? É importante que a escola também incentive os professores a utilizarem tais recursos.

Gráfico 4 - Proporção de professores que costumam e não costumam utilizar outros materiais didáticos além do livro, conforme categoria de desempenho da escola no IDEB (em \%).

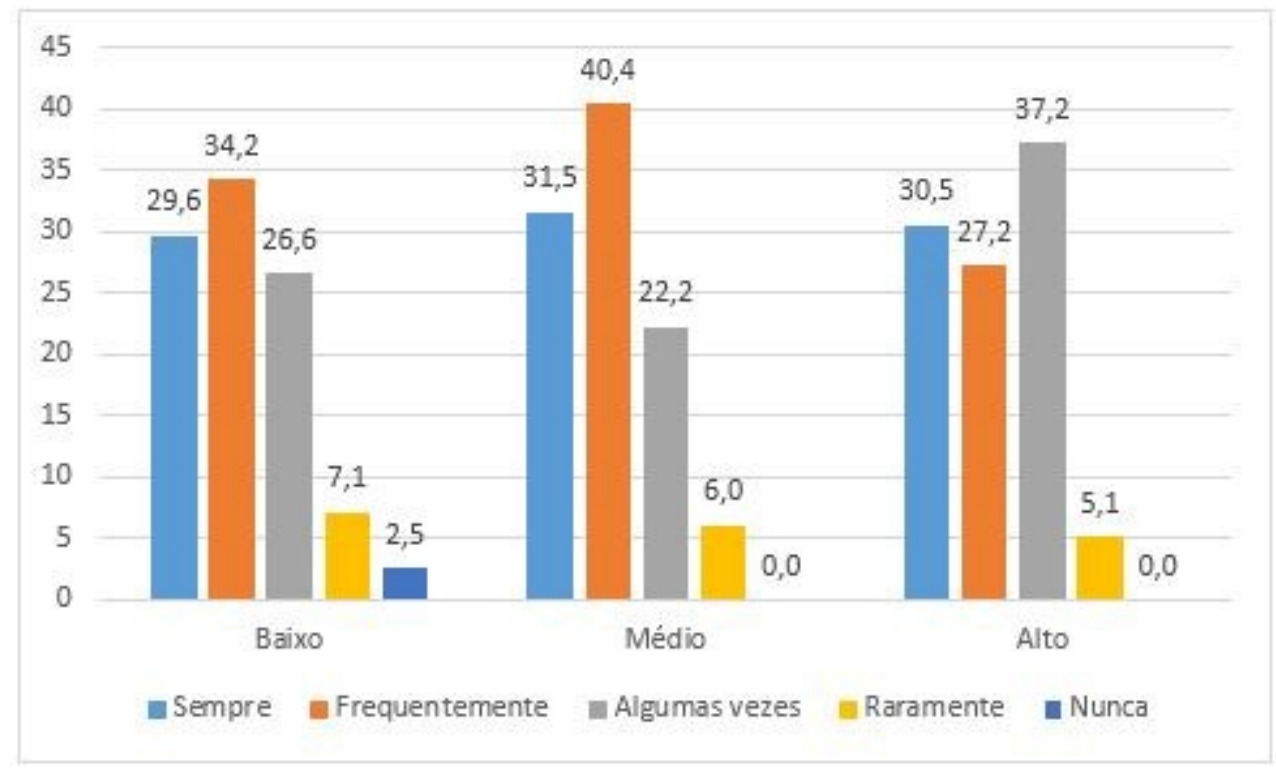

Fonte: Elaboração da autora

Os entrevistados foram questionados sobre os recursos utilizados por eles em sala de aula, dentre eles: televisão, data show, computador e internet. Uma grande parte dos professores relatou que utiliza recursos próprios, pois tem dificuldades de acessar os equipamentos por serem escassos ou por não funcionarem bem. A partir 
Atos de Pesquisa em Educação - ISSN 1809-0354

Blumenau, v. 12, n.3, p.705-730, set./dez. 2017

DOI: http://dx.doi.org/10.7867/1809-0354.2017v12n3p705-730

das entrevistas semiestruturadas, alguns professores levantaram a questão da escassez de recursos:

"Não, na verdade a escola tem, por exemplo, um data show, mas ele tem um limite de utilização na medida em que existe uma escala para esse material ser empregado em sala de aula. Então há uma dependência muito grande dessa escala para todos os professores e aí chega uma hora que você precisaria do aparelho e o outro professor, por exemplo, está com o direito da escala de utilizá-lo. [...] Aí a gente tenta fazer o que a gente chama de pulo do gato ao usar um notebook, ou um outro tipo de mídia que seja própria do professor e com isso ele tenta remediar essa dificuldade, essa falta". (J.D, Agosto, 2015).

"Não, o Estado ele deixa a desejar com relação a quantidade a mesma coisa ocorre com o livro didático, eles fazem um percentual que não é em cima daquele ano letivo é em cima de prognósticos anteriores. A quantidade de 2013 é a mesma em 2014. Lógico que a realidade é outra. Acontece a mesma coisa com a televisão. Você tem um colégio com 50 salas e vêm 20 televisores. É impossível cobrir tudo tá?" (A.N, Setembro, 2015)

"Não, eles não são suficientes para o total de professores. Tanto que eu tenho o meu que eu comprei para usar. [...] tinha um período que só tinha um data show para todos os professores da escola, e tinha que agendar, então era praticamente impossível que o professor conseguisse agendar e usasse em todas as aulas. Porque ficava tendo uma disputa na verdade entre os professores. [...] Então o acesso é bem limitado" (D.T, Outubro, 2015).

A partir das declarações dos professores é possível notar que ainda existe um grande desafio em relação à utilização de recursos que possam auxiliar na explicação do conteúdo em sala de aula. Muitas vezes o professor que deseja usar algum recurso específico é obrigado a utilizar recursos próprios ou comprar materias com seu dinheiro. Apesar do avanço da tecnologia, principalmente em relação a equipamentos voltados para o ensino, essas escolas ainda não possuem uma estrutura atualizada, contando assim com recursos ultrapassados.

Um dos maiores desafios é a implementação desses recursos, em bom estado e em número suficiente, para que seja possível aulas mais dinâmicas e que prendam mais a atenção do aluno. Também é necessário que os professores tenham preparação para utilizar esses recursos ou que haja técnicos voltados para a operação dos equipamentos. Outro desafio pode estar ligado à formação do professor, que muitas vezes não é preparado para a utilização de tecnologias dentro 
Atos de Pesquisa em Educação - ISSN 1809-0354

Blumenau, v. 12, n.3, p.705-730, set./dez. 2017

DOI: http://dx.doi.org/10.7867/1809-0354.2017v12n3p705-730

da sala de aula. É necessário, assim, conhecer a grade dos diversos cursos de licenciatura para investigar se existe, ou não, uma preparação desse profissional nesse sentido. Por isso, promover debates entre as licenciaturas em relação ao tema mostrará em que sentido a formação dos professores poderá ser melhorada.

Em relação à infraestrutura geral da escola, 49,2\% dos entrevistados do grupo baixo acreditam que ela é regular, seguido de $33 \%$ que acham que ela é boa (Gráfico 5). Já no grupo médio, 41,1\% acreditam que ela é regular e 40,7\% acreditam que é boa. Por fim, no grupo alto, 45,9\% dos entrevistados consideram ela boa contra $38,4 \%$ que acreditam que ela é regular. Os resultados estão concentrados nas respostas "boa" e "regular", mostrando que, na medida do possível, a infraestrutura dessas escolas tem atendido de alguma forma as necessidades dos alunos. Percebe-se também que não há uma grande diferença entre os três grupos.

Gráfico 5 - Opinião dos professores em relação a infraestrutura da escola em que trabalham (em \%).

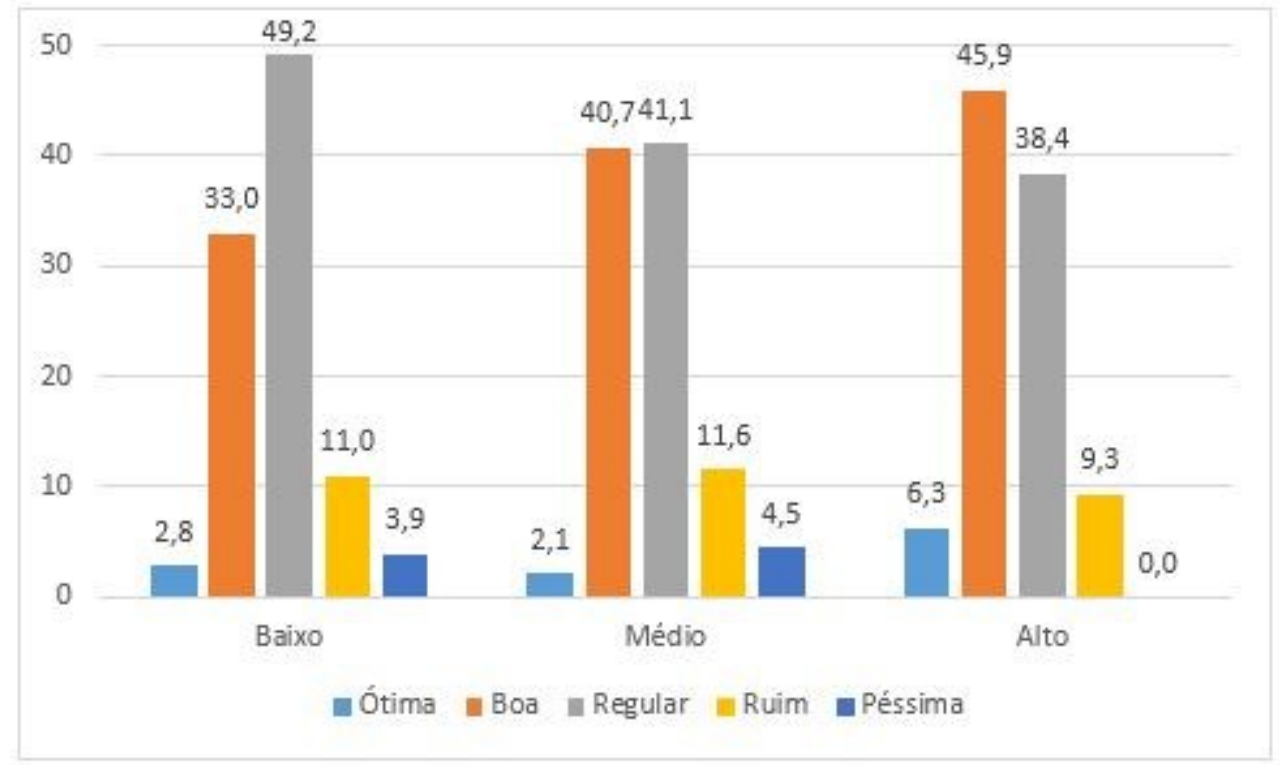

Fonte: Elaboração da autora

A infraestutura, seja física, seja de equipamentos, é parte fundamental para o processo de aprendizagem. Um local muito quente pode, por exemplo, dispersar ainda mais a atenção dos alunos que poderão ter dificuldades para se concentrarem. Um local muito barulhento também pode influenciar a sala de aula de forma negativa. Por isso, é fundamental analisar as principais deficiências, na 
Atos de Pesquisa em Educação - ISSN 1809-0354

Blumenau, v. 12, n.3, p.705-730, set./dez. 2017

DOI: http://dx.doi.org/10.7867/1809-0354.2017v12n3p705-730

estrutura ou nos equipamentos da escola, para melhorar os aspectos necessários. Quando os entrevistados foram questionados sobre a infraestrutura da escola, alguns responderam da seguinte maneira:

"Não. Na verdade a escola tem uma estrutura que atende basicamente a necessidade tanto dos alunos quanto dos professores e demais funcionários, mas ela tem todos os limites que os muitos anos de pouco investimento nessa parte estrutural e de infraestrutura dela né, legou através do tempo. Ou seja, nós temos uma escola hoje com uma aparência vamos dizer assim, de uma escola de mais de 30 anos atrás." (J.D, Agosto, 2015).

"Razoável, em termos de limpeza a escola é muito boa, nós temos uma biblioteca muito boa com títulos maravilhosos, que funciona realmente, mas o que é precário lá e não só lá, mas infelizmente na grande parte das escolas públicas é a questão de uma infraestrutura de mídia." (J. S, Novembro, 2015).

Ao descreverem duas escolas, Calderano, Barbacovi, e Pereira (2013) mostram a dificuldade do trabalho docente e atividade dos alunos. É mais difícil buscar a satisfação profissional, ensinar e aprender quando as condições materiais não são boas. Cada escola deve ter a oportunidade de listar suas principais dificuldades, assim é possível entender em que condições as notas do IDEB são obtidas. Mais uma vez, isso mostra a importância de estudos qualitativos na busca pela educação de qualidade; a infraestrutura é apenas um dos diversos fatores que precisa ser analisado diante do ambiente complexo da escola.

Outro fator importante a ser analisado é a "clientela" das escolas. A escola pode ter ótima infraestrutura e recursos, professores com excelente formação, entre outros fatores positivos, mas manter o interesse do aluno é um desafio ainda maior para a escola. Como tornar o ensino atrativo quando o aluno não é incentivado pelos reponsáveis? Como trabalhar com questões que ultrapassam o dever do professor? Muitas questões surgem na discurssão acerca da importância e a valorização que o aluno dá ao processo de aprendizagem.

Sobre o interesse dos alunos em sala de aula, os resultados dos três grupos se aproximam (Gráfico 6). Nas escolas do grupo baixo, 65,7\% dos professores acreditam que os alunos se mostram interessados algumas vezes, e 21,5\% acreditam que o interesse ocorre frequentemente. Já no grupo médio, 55,8\% acreditam que há interesse algumas vezes, contra 21,9\% que acreditam que ocorre 
Atos de Pesquisa em Educação - ISSN 1809-0354

Blumenau, v. 12, n.3, p.705-730, set./dez. 2017

DOI: http://dx.doi.org/10.7867/1809-0354.2017v12n3p705-730

frequentemente. Por fim, no grupo alto $55,6 \%$ dos entrevistados acreditam que há interesse algumas vezes e $23,9 \%$ pensam que isso ocorre frequentemente.

Gráfico 6 - Nível de interesse dos alunos nas aulas (em \%).

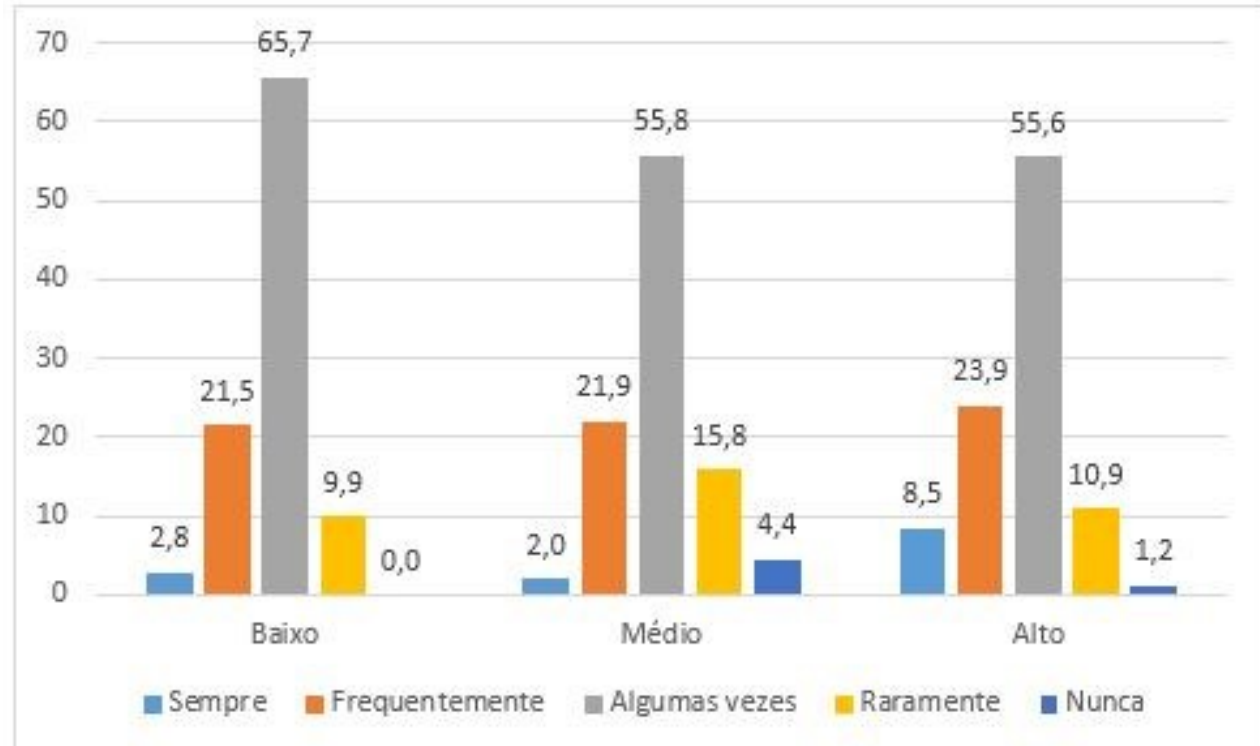

Fonte: Elaboração da autora

Apesar dos resultados, os dados qualitativos mostram outro fator quando os professores são questionados sobre o interesse dos alunos em sua aula:

"Olha, uma turma ela é muito diversificada, então você tem uma pequena parte da turma que já vem com esse interesse, né? Eu diria uns 10 a $15 \%$ e mais uns $10 \%$ ai se esforça para uma outra questão que talvez não seja nem da sala de aula, mas que ele traz de casa que é a exigência da família dele estudar de ter a nota, de ter um bom boletim." (E.C, Setembro, 2015).

"Olha só, nessa pergunta eu queria responder fazendo uma comparação. Eu comparo os alunos da rede pública da zona rural e da zona urbana. Eu considero os alunos da zona rural, como é o nosso caso, mais interessados do que o da urbana, então não vou te dizer que $100 \%$ dos alunos são interessados, isso eu não tenho. Eu tenho alunos de terceiro ano de ensino médio, que acham que estão naquela fase de que estou no terceiro então eu já passei, não preciso estudar... tem essa fase. De outro lado tem alunos de ensino médio do segundo ano que tem perspectiva. Tem alguns... São todos? Não, não são todos. Mas comparando a rede pública da zona rural, com a rede pública da zona urbana, porque eu trabalho nas duas, então eu percebo aqui um pouco mais de expectativa do que em outra escola, percebo isso." (T.W, Outubro, 2015). 
O interesse do aluno é fundamental para que ele possa de fato aprender. Contudo, muitas vezes se torna um grande desafio para o professor convencê-lo da importância do ensino e até mesmo tornar suas aulas mais atrativas. Mas o que torna um aluno interessado? Como é possível convencê-lo de que estudar pode melhorar o seu futuro? Como ultrapassar as barreiras impostas pelas características socioeconômicas? Muitas perguntas surgem, porém é uma tarefa difícil respondêlas.

Em relação à frequência com que os professores chamam a atenção dos alunos nas aulas, nota-se que os resultados dos grupos baixo e médio são próximos (Gráfico 7). A maior diferença aparece em relação ao grupo alto. Enquanto 35,7\% dos entrevistados do grupo baixo chamam atenção de seus alunos frequentemente, tal proporção cai para $29,3 \%$ no grupo de escolas de melhor IDEB. As interrupções em sala de aula podem ser muito prejudiciais para toda turma, por isso analisar a frequência com que uma aula deve ser interrompida para que seja possível dar continuidade às explicações é importante.

Talvez uma turma esteja com muitos alunos, o que torna a sala mais barulhenta e difícil de separar os "grupos". Talvez algum aluno esteja passando por problemas em casa, o que pode torná-lo disperso ou com atitudes para chamar a atenção. De fato são diversos fatores que podem influenciar o comportamento de um aluno em sala de aula, por isso é fundamental que haja acompanhamento desses alunos por meio de assistentes sociais, psicólogos, e até mesmo da família, para entender melhor as dificuldades de cada um.

Gráfico 7 - Frequência que os professores chamam a atenção dos alunos nas aulas (em \%). 
Atos de Pesquisa em Educação - ISSN 1809-0354

Blumenau, v. 12, n.3, p.705-730, set./dez. 2017

DOI: http://dx.doi.org/10.7867/1809-0354.2017v12n3p705-730

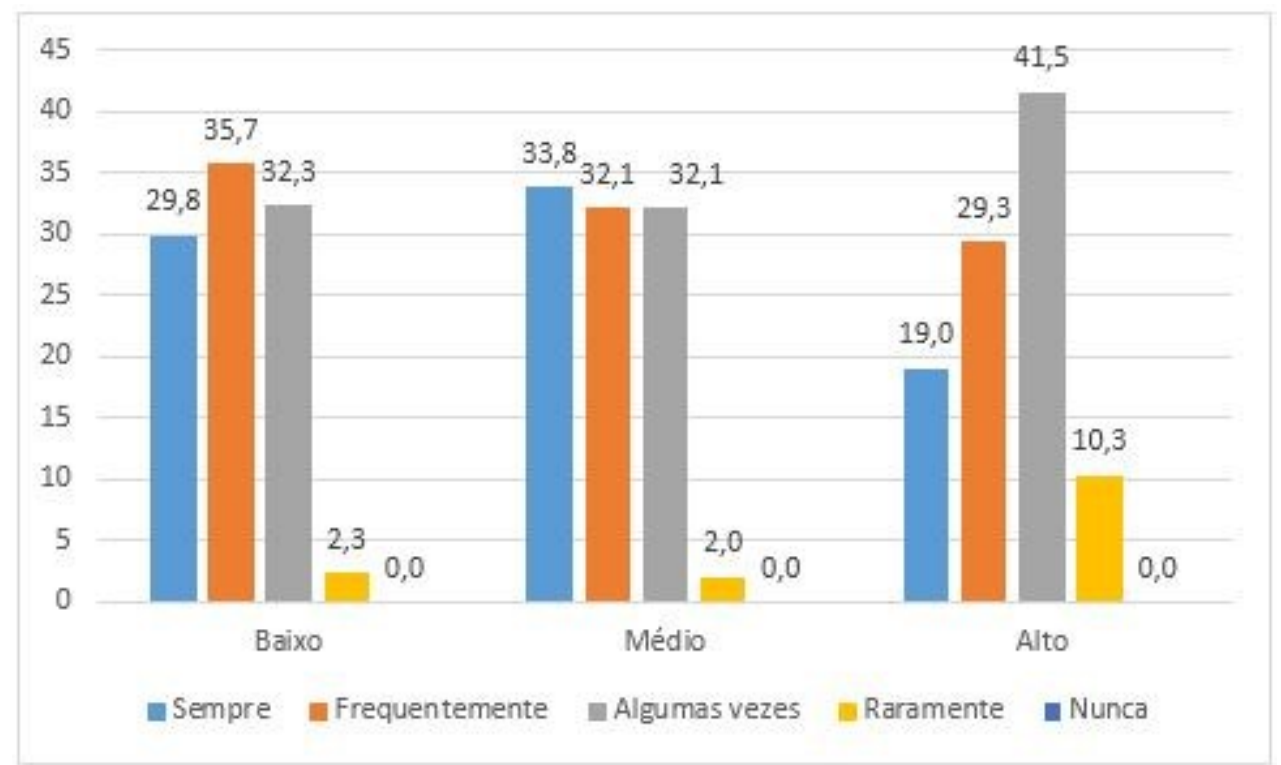

Fonte: Elaboração da autora

Os professores foram questionados sobre o interesse dos responsáveis dos alunos no desempenho deles como mostra o Gráfico 8. Os resultados mostram que no grupo baixo, 52,9\% dos entrevistados acreditam que esse interesse é muito baixo, contra 35,1\% que pensam que é baixo. Já no grupo Médio, 61,7\% disseram que o interesse dos responsáveis é muito baixo, enquanto $26,1 \%$ acreditam que é razoável. Por fim, no grupo alto $38,4 \%$ pensam que o interesse é baixo, contra $33,1 \%$ que acreditam que é muito baixo.

Gráfico 8 - Nível de interesse dos responsáveis dos alunos na educação (em \%).

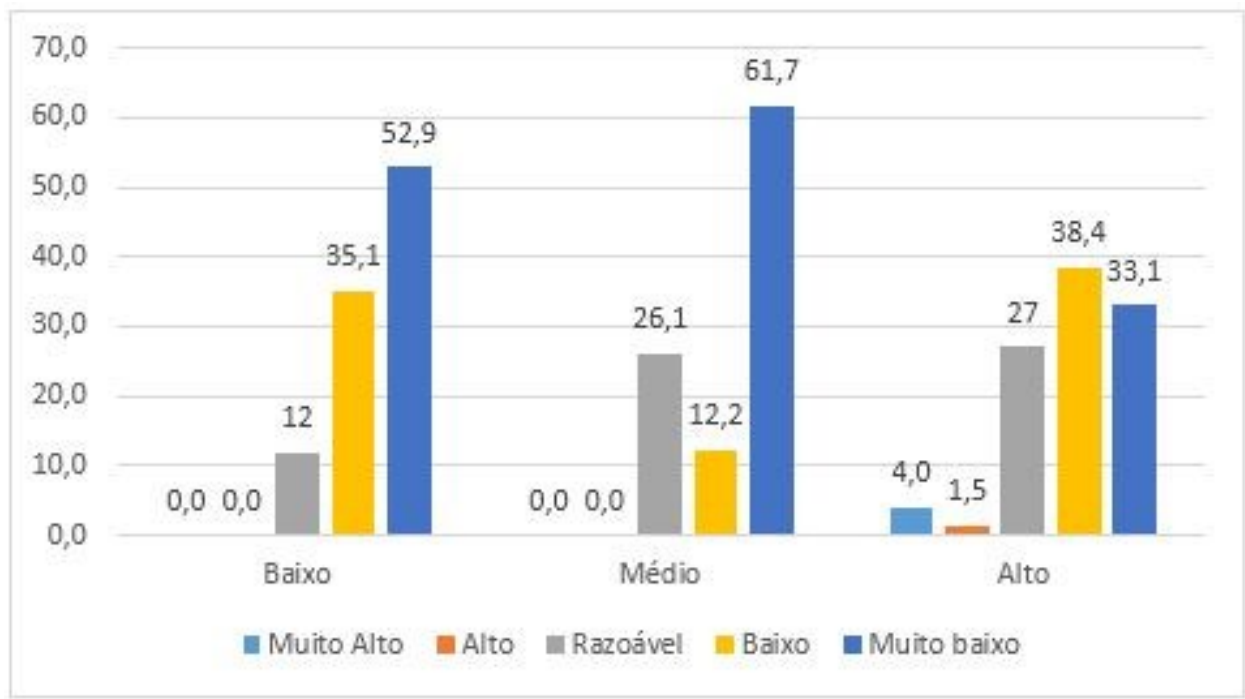

Fonte: Elaboração da autora 
Atos de Pesquisa em Educação - ISSN 1809-0354

Blumenau, v. 12, n.3, p.705-730, set./dez. 2017

DOI: http://dx.doi.org/10.7867/1809-0354.2017v12n3p705-730

Nota-se que nenhum professor afirmou que o interesse dos responsáveis é muito alto. Como já foi mencionado, o acompanhamento dos responsáveis é necessário para o aluno se sentir motivado. Na entrevista, quando os professores foram questionados sobre se há uma grande participação dos pais no dia-a-dia escolar do filho, alguns responderam:

"Não. Não há uma grande participação. Não, normalmente eles, se você for considerar ensino fundamental eles até procuram lá no final do ano quando o aluno está praticamente precisando de 9 pra passar. Ensino médio muito difícil alguém aparecer para me procura. E o que eu sempre falo que, respondendo até aquele seu questionário, um dos itens para se avaliar a qualidade do ensino hoje seria a participação da família, a maior participação da família na vida escolar, porque isso é importante, porque hoje o aluno tem uma série de outros interesses, é a internet, é o face, é o whatsapp, então tem uma série, jogos, é computador, o estudar mesmo está ficando para segundo e terceiro plano. Então por mais que o professor em sala de aula foque nessa perspectiva falta muito a presença da família também incentivando o aluno." (T.W, Outubro, 2015).

"Nenhum. Por que na verdade o que acontece, pelo menos na rede pública, é muito difícil o responsável procurar o professor, procurar a escola para estar, por exemplo, sabendo o desempenho do seu filho, do aluno, com relação a notas, com relação a frequência, se veio para a escola e se entrou, se não está matando aula. Como a gente tem as vezes uma gama de programas assistenciais, bolsa família, escola... essas coisas não estou entrando no mérito político, mas é muito comum você se deparar com uma triste realidade, o responsável só procura a escola pra saber o que está acontecendo com o filho dele quando na verdade a bolsa família foi cortada, porque já foi enviado não sei para que órgão, porque não sou dessa área, um quantitativo de faltas que impede que a bolsa família seja liberada aí ele vem mais pelo dinheiro, pelo benefício do que pela preocupação com o rendimento do filho na escola." (J. S, Novembro, 2015).

"Por exemplo, sala com 50, sala com 40 eu tenho 8 eu tenho 4 que vão pra UENF, que realmente estão querendo, esses aí os pais são presentes. São presentes porque o aluno produz. Então a gente percebe isso. Entendeu? A sociedade deixou uma sobrecarga muito grande sobre nós professores. Infelizmente isso não pode continuar. Não pode continuar de maneira alguma. Eu dou educação enquanto ela é intelectual, eu não dou educação comportamental. Educação comportamental vem de casa." (A.N, Setembro, 2015).

Alguns professores apontaram que os pais só se interessam pelos programas assistenciais e estariam mais preocupados com o fluxo escolar do filho do que em 
Atos de Pesquisa em Educação - ISSN 1809-0354

Blumenau, v. 12, n.3, p.705-730, set./dez. 2017

DOI: http://dx.doi.org/10.7867/1809-0354.2017v12n3p705-730

seu desempenho. Outros apontaram que nunca tiveram qualquer tipo de contato com algum responsável de aluno. Isso mostra que pode não estar havendo nessas escolas interação escola-professores-responsáveis. Mas como mudar esse tipo de comportamento? Como mostrar aos pais a importância de incentivar os filhos, bem como acompanhá-los em seu dia-a-dia? Apesar do grande desafio, sugere-se que as escolas, bem como o poder público, busquem integrar mais os pais ao cotidiano das escolas através de palestras que expliquem a importância do ensino na vida do aluno.

Uma das questões mais discutidas da década de 1990, e nos dias atuais, é a utilização de avaliações externas com o objetivo de analisar o ensino das escolas para melhorar a educação como um todo. O IDEB tem sido destaque como principal política nacional de avaliação. A ferramenta é utilizada principalmente para diagnosticar a qualidade da educação das escolas públicas. Dada a sua importância no contexto atual, os professores também foram questionados sobre esse instrumento. O mais surpreendente da pesquisa de campo foi se deparar com professores que não faziam ideia do que era o IDEB e para que ele servia. Outros professores se mostraram insatisfeitos, principalmente com as comparações de notas das escolas que ocorrem.

Em relação aos resultados sobre a opinião dos professores acerca de o IDEB ser um bom indicador para medir a qualidade da educação básica, o grupo baixo e médio são muito próximos; respectivamente, $78,3 \%$ e $75,1 \%$ acreditam que o IDEB não é um bom indicador (Gráfico 9). Já no grupo alto, tal proporção cai para 60,6\%. Isso mostra a grande insatisfação dos professores em relação ao indicador, até mesmo nas escolas de melhor desempenho.

Gráfico 9 - Proporção de entrevistados que acreditam que o IDEB é um bom indicador para medir a qualidade da educação básica (em \%) 
Atos de Pesquisa em Educação - ISSN 1809-0354

Blumenau, v. 12, n.3, p.705-730, set./dez. 2017

DOI: http://dx.doi.org/10.7867/1809-0354.2017v12n3p705-730

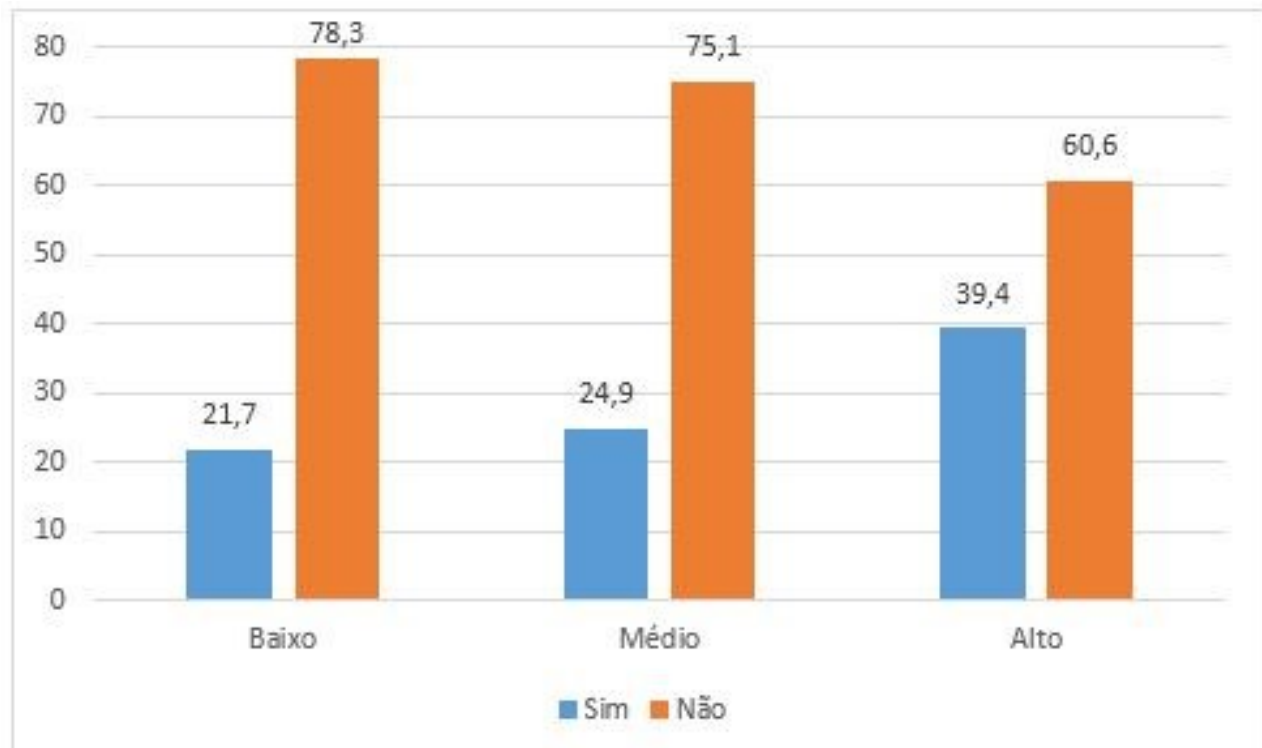

Fonte: Elaboração da autora

O IDEB é utilizado como base para tomada de decisões em relação à melhoria da qualidade da educação básica. Se os professores, atores diretamente ligados ao ensino, mostram-se insatisfeitos com o indicador, é provável que haja falhas e, por isso, surge a necessidade de rever o instrumento com auxílio dos professores, diretores, alunos, comunidade e todos aqueles que estão direta e indiretamente ligados à escola.

"Eu vejo a questão do IDEB, muitas vezes como algo mascarado e fantasioso, seja proposital ou por algumas razões mesmo. Porque nem sempre um nível de aprovação alto, elevado significa um nível de rendimento de aprendizado real, de acordo com que o gráfico mostra. Por exemplo, porque se há eventos na escola, muitas das vezes é quase que obrigatório, não estou dizendo que seja obrigatório, mas há uma pressão para pontuar a participação do aluno, então fez o SAERJ é ponto, fez não sei o que é ponto, há muitos mecanismos de dá o empurrãozinho, então no final você tem às vezes um nível de aprovação que se não fossem esses empurrãozinhos de repente o aluno ficaria retido. Então a gente tem essa coisa, por exemplo, o aluno fez o SAERJ, ele nem leu o texto, ele não se preocupou em resolver as questões e em cinco minutos, dez minutos ele fez uma marcação aleatória no cartão de resposta, ele não pensou, né? Aí você dá o ponto de participação. Mas o que aquilo acrescentou na vida do aluno? [...] Eu acho muito falho a forma como esse IDEB é apresentado, existem muitas formas dos resultados serem mascarado de forma proposital, né?" (J.S, Novembro, 2015) 
Atos de Pesquisa em Educação - ISSN 1809-0354

Blumenau, v. 12, n.3, p.705-730, set./dez. 2017

DOI: http://dx.doi.org/10.7867/1809-0354.2017v12n3p705-730

Como levantado por muitos professores, o IDEB é importante, mas ele não pode ser considerado o único instrumento. Existem questões que não são mensuradas por meio do indicador e que influenciam de alguma maneira a qualidade do ensino. Variáveis, como nível socioeconômico dos alunos, condição de trabalho dos professores, infraestrutura, recursos, gestão educacional, formação dos professores, etc. (RONCA, 2013), são algumas das questões que fazem parte do cotidiano escolar e muitas vezes não são levadas em conta. Dessa forma, ocorrem comparações entre as escolas sem qualquer tipo de critério e até mesmo com uma análise equivocada dos resultados, sem contar que muitas vezes essas notas podem não representar determinada escola.

"Olha eu acho que a gente não pode comparar escola diferentes com contexto sociais diferentes, escola grande com escola pequena, escola perto de periferia com escola de bairro, próximo a um bairro de classe média. A gente tem que ter avaliações obviamente, mas não dá pra colocar escolas diferentes no mesmo bojo, acho que a disputa é meio desigual, né? Eu acho que essa política aí de meritocracia na educação eu particularmente sou completamente contra." (K. P, Setembro, 2015).

Muitos professores levantaram a necessidade da contextualização, até mesmo os entrevistados das escolas com o IDEB alto citaram a questão da "clientela" como um dos principais fatores relacionados à nota. A questão do tamanho da escola também se mostra como fator importante na opinião dos professores. Alguns professores apontaram que as escolas menores, do interior de Campos, por exemplo, possuem mais alunos interessados, comparando-se às escolas do centro. Mesmo com todas as críticas, o indicador ainda é o instrumento mais utilizado para se analisar a qualidade da educação básica.

Por isso, os professores foram questionados se o IDEB tem contribuído para melhorar o ensino da escola em que trabalham (Gráfico 10). A grande maioria dos entrevistados do grupo baixo, 86,3\%, acreditam que o IDEB não contribui para melhorar o ensino da escola em que trabalham, e apenas $13,7 \%$ acreditam que ele contribui. Já no grupo médio e alto, respectivamente, $75,1 \%$ e 58,9\% acreditam que o indicador não contribui para a melhoria da educação. 
Gráfico 10 - Opinião dos professores sobre se o IDEB tem contribuído para melhorar o ensino da escola em que trabalham (em \%).

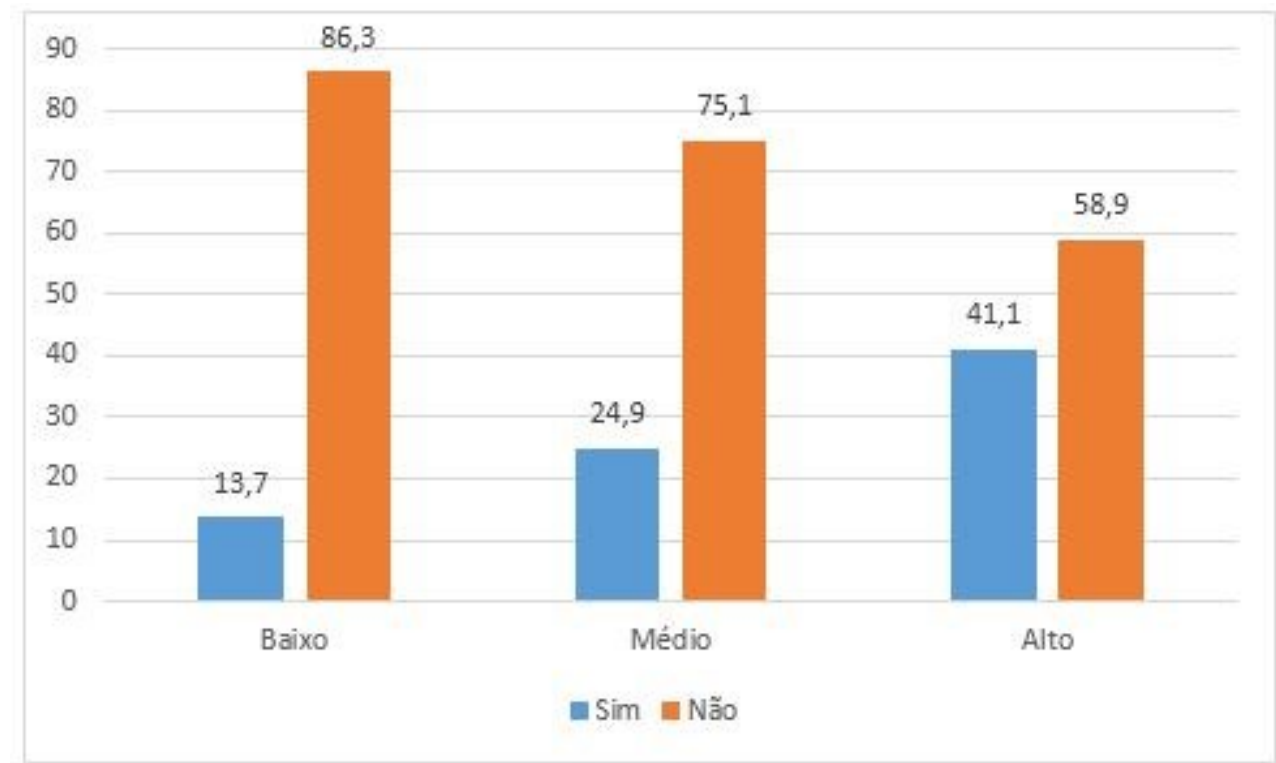

Fonte: Elaboração da autora.

Os resultados chamam atenção para a qualidade do índice, pois a grande maioria dos entrevistados, mesmo das escolas de IDEB mais elevado, não considera que o indicador é eficiente para medir a qualidade da educação. $\mathrm{Na}$ entrevista semiestruturada, um dos entrevistados respondeu:

"Nem um pouco, é completamente uma farsa. É uma farsa, tá? Não avalia nada, por outro lado o aluno também... eles não leem, não leem o Saerjinho, não leem o Saerj, não leem nada. Eles querem marcar só os pontinhos lá e entregar a prova e ir para casa o mais rápido possível [...]. Muitas vezes quando estou de férias eles modificam as notas dos alunos para aumentar o fluxo, aumentar o IDEB e aumentar a verba." (K.M, Outubro, 2015).

Além disso, como o IDEB é a junção de duas variáveis quantitativas (Prova Brasil + Fluxo Escolar), é fácil manipular esses dados, o que exige maior fiscalização na hora do cálculo de determinada escola. Pensando na importância de outras variáveis para a análise da qualidade da educação, os professores contribuíram com algumas sugestões por meio de uma pergunta semiaberta do questionário e da entrevista. As variáveis podem ser observadas no Quadro 2. 
Atos de Pesquisa em Educação - ISSN 1809-0354

Blumenau, v. 12, n.3, p.705-730, set./dez. 2017

DOI: http://dx.doi.org/10.7867/1809-0354.2017v12n3p705-730

\begin{tabular}{|l|}
\hline Infraestrutura da escola \\
\hline Formação dos professores \\
\hline Projetos desenvolvidos dentro da realidade escolar \\
\hline Remuneração dos professores \\
\hline Participação dos pais dos alunos \\
\hline Clientela \\
\hline Interesse dos alunos \\
\hline Participação e motivação dos professores \\
\hline Disponibilidade de material adequado \\
\hline Planejamento das aulas \\
\hline Desempenho em sala de aula \\
\hline Profissionais de apoio (Assistente social, psicólogo, inspetores...) \\
\hline Sensação de segurança dos profissionais e alunos \\
\hline Recursos digitais e materiais didáticos disponíveis \\
\hline Avaliar o limite da escolaridade do aluno \\
\hline Perfil do aluno \\
\hline Contexto socioeconômico \\
\hline Bairro e localidade da escola \\
\hline Quantidade de aluno por sala de aula \\
\hline Livro didático \\
\hline Fonte: Elaboração da autora. \\
\hline
\end{tabular}

Os pontos levantados pelos professores que constam no Quadro 2 são os que mais apareceram durante a pesquisa, contudo foram sugeridas mais de 150 variáveis mostrando a importância da participação do professore no processo de avaliação da educação. O universo escolar é complexo e, por isso, existem diversos fatores que devem ser considerados.

Assim, a pesquisa permitiu a compreensão de alguns fatores presentes no cotidiano escolar que não são considerados pelo IDEB. Fatores que podem contribuir de forma positiva ou negativa no processo de aprendizagem do aluno. A partir da pesquisa de campo, sugere-se uma maior participação dos professores nesse tipo de avaliação, além de mais pesquisas com abordagens qualitativas que visem a analisar a realidade de cada escola, buscando entender as especificidades existentes bem como seus maiores desafios. 
Atos de Pesquisa em Educação - ISSN 1809-0354

Blumenau, v. 12, n.3, p.705-730, set./dez. 2017

DOI: http://dx.doi.org/10.7867/1809-0354.2017v12n3p705-730

Uma mesma política aplicada a realidades distintas pode não ter o efeito esperado, por isso é necessário entender melhor cada contexto e assim criar políticas voltadas especificamente para as diferentes escolas. Entender as complexidades existentes dentro e fora dos muros escolares é um grande desafio que deve ser enfrentado para que a busca pela educação pública de qualidade esteja mais próxima da realidade.

\section{CONSIDERAÇÕES FINAIS}

O Índice de Desenvolvimento da Educação Básica (IDEB) se apresenta como uma das principais ferramentas de tomada de decisões do governo em relação à educação. A partir dele são criadas políticas públicas com o intuito de melhorar a qualidade da educação básica. O IDEB possui caráter de diagnóstico da qualidade do ensino básico, mostrando aos gestores educacionais e demais interessados onde a educação tem apresentado melhoria e onde não tem ocorrido avanços. Embora seja um importante indicador, ele tem sido alvo de críticas principalmente por apenas considerar a Prova Brasil e o Fluxo Escolar em seu cálculo.

Dada a importância de estudos com abordagens qualitativas para entender melhor realidades específicas, o presente estudo buscou combinar esta abordagem com a quantitativa, com o intuito de entender melhor o contexto de nove escolas, no município de Campos dos Goytacazes, que possuem notas do IDEB mais altas, média e mais baixas. Muitos professores se mostravam inseguros para falar do IDEB durante a pesquisa, pois não entendiam bem como o indicador funcionava e para que servia. Outros afirmavam que os alunos não entendiam a importância do exame e não eram preparados para realizá-lo. Dessa forma, a visão do professor pode colaborar em análises mais profundas das escolas e auxiliar em uma melhora na qualidade da educação.

Sobre o desempenho no IDEB das escolas que participaram da pesquisa de campo, nota-se que o grupo de notas mais altas possui um histórico de crescimento em seu desempenho. São escolas menores que estão localizadas mais distantes do centro. Já o grupo médio surpreende principalmente com a escola $F$, que teve o maior IDEB do município em 2009, igual a 4,1, contudo apresentou uma queda para 
Atos de Pesquisa em Educação - ISSN 1809-0354

Blumenau, v. 12, n.3, p.705-730, set./dez. 2017

DOI: http://dx.doi.org/10.7867/1809-0354.2017v12n3p705-730

3,4, em 2013, o que leva ao questionamento sobre o que teria influenciado essa queda na "qualidade"; apenas a disponibilização dos resultados das escolas não permite fazer tal análise. Sobre as escolas do grupo baixo, todas estão localizadas no centro da cidade. Dentre elas, os resultados da escola I são os que mais surpreendem, pois apresentam queda no decorrer dos anos, passando de 3,6, em 2009, para 2,8, em 2013. Dessa forma, o que diferencia uma escola com alto desempenho de uma escola com baixo desempenho? Foi exatamente isso que o artigo buscou analisar.

A partir dos resultados dos questionários e entrevistas, é possível notar que não há uma grande diferença entre a infraestrutura e formação dos professores das escolas do grupo baixo, médio e alto desempenho no IDEB. As diferenças entre elas estão mais em sua localização e nas diferenças de interesses de pais e alunos no processo de ensino-aprendizagem. As escolas de maior IDEB estão mais longe do centro da cidade e possuem alunos e pais mais interessados do que as escolas com menor IDEB. Há também a denúncia da prática de "gaming" por parte das escolas para melhorar o IDEB e não ser penalizada pelo Estado. Mesmo os professores das escolas do grupo de melhor desempenho não acreditam que o indicador esteja contribuindo para a melhoria da qualidade da educação

\section{LUANA HESPANHOL DE SOUZA}

Mestre em Políticas Sociais. Bacharelado em Economia pela Universidade Federal Fluminense - UFF.

\section{MARLON GOMES NEY}

Doutor em Economia Aplicada pela UNICAMP. Professor do Programa de PósGraduação em Políticas Sociais da Universidade Estadual do Norte Fluminense UENF.

\section{PAULO MARCELO DE SOUZA}

Doutor em Economia Aplicada pela UFV.

\section{REFERÊNCIAS}

ALVES, M. T. G.; SOARES, J. F. Contexto escolar e indicadores educacionais: condições desiguais para a efetivação de uma política de avaliação educacional. 
Atos de Pesquisa em Educação - ISSN 1809-0354

Blumenau, v. 12, n.3, p.705-730, set./dez. 2017

DOI: http://dx.doi.org/10.7867/1809-0354.2017v12n3p705-730

Educação e Pesquisa, São Paulo, v. 39, n. 1, p. 177-194, jan./mar. 2013. Disponível em: <http://www.scielo.br/pdf/ep/v39n1/v39n1a12.pdf>. Acesso em: 18 abr. 2016.

BOURDIEU, P. Os três estados do capital cultural. In: NOGUEIRA, M. A.; CATANI, A. (Orgs). Escritos de educação. 10 ed. Petrópolis, RJ: Vozes, 2008. p. 71 - 79. (Ciência sociais da educação).

BOURDIEU, P. A escola conservadora: a desigualdade frente à escola e à cultura. In :NOGUEIRA, M. A.; CATANI, A. (Orgs). Escritos de educação. 10 ed. Petrópolis, RJ: Vozes, 2008. p. 39 - 64. (Ciência sociais da educação).

SILVA, L. H.; MORAIS, T. C.; BOF, A. M.; et al. A educação no Brasil. Brasília: Instituto Nacional de Estudos e Pesquisas Educacionais Anísio Teixeira, 2006.

CALDERANO, M. A.; BARBACOVI, L. J.; PEREIRA, M. C. (Org.) O que o Ideb não conta? Processos e resultados alcançados pela escola básica. Juiz de Fora: Editora UFJF, 2013.

CRUZ, P.; MONTEIRO, L. (Org.). Anuário Brasileiro da Educação Básica. São Paulo: Editora Moderna, 2013. 148 p. Disponível em:

<http://www.moderna.com.br/lumis/portal/file/fileDownload.jsp?fileld=8A8A8A833F33 698B013F346E30DA7B17>. Acesso em: 22 nov. 2015.

DALMORO, M.; VIEIRA, K. M. Dilemas na construção de escalas tipo likert: o número de itens e a disposição influenciam nos resultados? Revista de Gestão Organizacional, Santa Catarina, v. 6, ed. Especial, p. 161-174, 2014. Disponível em: <https://bell.unochapeco.edu.br/revistas/index.php/rgo/article/viewFile/1386/1184>. Acesso em: 18 Abr. 2016

FERNANDES, R.; GREMAUD, A. Qualidade da educação básica: avaliação, indicadores e metas. In: VELOSO, F. et al. (Orgs.). Educação básica no Brasil: construindo o país do futuro. Rio de Janeiro: Elseiver, 2009. p. 213-238.

GOVERNO DO RIO DE JANEIRO. Cadernos de políticas públicas do Rio de Janeiro. Disponível em:

<http://www.rio.rj.gov.br/dlstatic/10112/4379008/4130264/EducacaoPORT1211.pdf> Acesso em: 19 de Jun. de 2015.

IBGE. Cidade: Campos dos Goytacazes/RJ, 2017. Disponível em:

<https://cidades.ibge.gov.br/brasil/rj/campos-dos-goytacazes/panorama> Acesso em: 12 de Dez. de 2017.

LIKERT, R. A technique for the measurement of attitudes. New York: Archives of Psychology, v. 22, n. 140, p. 44-53,1932.

MACHADO, C.; ALAVARSE, O. M. Qualidade das escolas: tensões e potencialidades das avaliações externas. Educação e Realidade, Porto Alegre, v. 39, 
Atos de Pesquisa em Educação - ISSN 1809-0354

Blumenau, v. 12, n.3, p.705-730, set./dez. 2017

DOI: http://dx.doi.org/10.7867/1809-0354.2017v12n3p705-730

n. 2, p. 413-436, abr./jun. 2014. Disponível em:

<http://www.scielo.br/pdf/edreal/v39n2/v39n2a05.pdf>

OLIVEIRA, R. P.; ARAUJO, G. C. Qualidade do ensino: uma nova dimensão da luta pelo direito à educação. Revista Brasileira de Educação, São Paulo, n. 28, p. 5-24, jan./fev./mar./abr. 2005. Disponível em:

<http://www.scielo.br/pdf/rbedu/n28/a02n28>. Acesso em: 18 abr. 2016.

RONCA, A. C. C. Avaliação da educação básica: seus limites e possibilidades. Retratos da Escola, Brasília, v. 7, n. 12, p. 77-86, jan./jun. 2013. Disponível em: <http://www.esforce.org.br/index.php/semestral/article/view/262>. Acesso em: 18 abr. 2016. 